DOI: $10.46730 /$ japs.v2i1.41

\title{
Tinjauan Normatif Penjualan BBM Subsidi Berdasarkan Undang-Undang Republik Indonesia Nomor 22 Tahun 2001 Tentang Minyak Dan Gas Bumi
}

\author{
Boy Muhammad Putra, Ardiansah, Bagio Kadaryanto ${ }^{1}$ \\ ${ }^{1}$ Pascasarjana Hukum, Universitas Lancang Kuning. \\ Email : Boymhdputra13@gmail.com, ardiansah@unilak.ac.id, bagio.kardayanto@unilak.ac.id
}

Kata kunci

Keywords

Abstract

\begin{abstract}
Abstrak
Dalam perkembangannya pendistribusian minyak bersubsidi mengalami kelangkaan. Sementara mayoritas industri yang ada di masyarakat banyak mempergunakan BBM. Misalkan, kebijakan Subsidi BBM jenis solar kepada masyarakat menurut banyak kalangan merupakan hal yang dilematis. Disatu sisi masyarakat membutuhkannya namun subsidi justru menguntungkan industry besar yang masih menggunakan BBM jenis solar. Di tengah kondisi sulit yang di hadapi oleh Pemerintah, akibat semakin meningkatnya permintaan BBM Bersubsidi dan naiknya harga BBM di pasar dunia, ada pihak-pihak tertentu baik perseorangan maupun korporasi yang melakukan perbuatan tidak bertanggung jawab berupa: pengoplosan, penimbunan, penyelundupan, pengangkutan dan penjualan kepada industri BBM Bersubsidi. Penelitian ini melihat menganalisis tinjauan normative terhadap penjualan BBM Subsidi dan menganalisis system pengawasan penyelewengan penjualan BBM Subsidi kepada industri yang dilakukan SPBU berdasarkan UndangUndang Republik Indonesia Nomor 22 Tahun 2001 tentang Minyak Dan Gas Bumi. Dengan menggunakan pendekatan penelitian kualitatif, dengan melakukan tinjauan yang bersifat normative terhadap penjualan BBM Subsidi Berdasarkan Undang-Undang Republik Indonesia Nomor 22 Tahun 2001. Sumber data berasal dari data sekunder, primer dan bahan Hukum Tertier. Pengumpulan data menggunakan teknik studi documenter/studi kepustakaan. Hasil penelitian mendapati dalam UU No. 22 tahun 2001 telah termuat konsep penyelenggaraan kegiatan usaha migas, konsep penguasaan kemigasan, konsep penyediaan dan pemanfaatan kemigasan, konsep pengusahaan kemigasan dan konsep kelembagaan kemigasan. Sedangkan untuk implementasinya di Indonesia, penyediaan dan Pemanfaataan Gas Bumi dilaksanakan melalui berbagai aturan hukum yang telah ada.
\end{abstract}




\begin{tabular}{ll}
\hline Penjualan, BBM & In its development, the distribution of subsidized oil is scarce. \\
Subsidi, Minyak, Gas & Meanwhile, the majority of industries in society use a lot of BBM. \\
Bumi & For example, the policy of subsidizing diesel fuel to the public is a \\
& dilemma. On the one hand, people need it, but subsidies actually \\
benefit large industries that still use diesel fuel. In the midst of the & difficult conditions faced by the Government, due to the increasing \\
demand for subsidized fuel and rising fuel prices on the world \\
market, there are certain parties, both individuals and corporations \\
who commit irresponsible actions in the form of mixing, hoarding, \\
smuggling, transporting and selling to industry Subsidized BBM. \\
This study looks at analyzing a normative review of subsidized fuel \\
sales and analyzing the supervision system of subsidized fuel sales to \\
the industry by gas stations based on Law of the Republic of \\
Indonesia Number 22 the Year 2001 concerning Oil and Gas. By \\
using a qualitative research approach, by conducting a formative \\
review of the sale of subsidized fuel based on the Law of the Republic \\
of Indonesia Number 22 of 2001. Data sources come from secondary \\
data, primary and Tertiary Law materials. Collecting data using \\
documentary study techniques/literature study. The research results \\
found in Law no. 22 of 2001 contains the concept of organizing oil \\
and gas business activities, the concept of controlling oil and gas, the \\
concept of supply and utilization of oil and gas, the concept of oil \\
and gas exploitation, and the concept of oil and gas institutions. \\
Meanwhile, for its implementation in Indonesia, the provision and \\
utilization of Natural Gas are carried out through various existing \\
legal regulations.
\end{tabular}

\section{Pendahuluan}

Pelayanan Publik merupakan tanggung jawab negara kepada masyarakatnya (Afrizal, 2020). Salah satunya adalah pelayanan dalam mengelola semua yang berkaitan dengan bahan bakar minyak (WIndayanti, 2019). Dalam hal ini, bahan bakar minyak merupakan kebutuhan dasar bagi manusia terutama dalam industri di seluruh dunia. Hal yang perlu di ingat, bahwa bahan bakar minyak merupakan sumber daya alam yang tidak dapat diperbaharui. Kebutuhan bahan bakar minyak baik dalam bidang industri maupun transportasi semakin hari semakin meningkat karena mesin-mesin tersebut membutuhkan bahan bakar minyak dan dapat menyebabkan danya kelangkaan bahan bakar minyak tersebut, namun kebutuhan yang semakin tinggi terhadap BBM tidak didukung dengan sumber daya alam yang mengalami penurunan (Wida, 2019).

Dewasa ini, subsidi BBM diberikan oleh Pemerintah kepada Perusahaan Tambang Minyak Negara (Pertamina) dalam bentuk aliran uang (cash). Pola ini mengandung kelemahan bahwa subsidi BBM tidak tepat menjangkau kelompok masyarakat yang pantas memperoleh, sehingga mendorong PERTAMINA untuk lebih efisien dalam menjalankan tugasnya menyediakan BBM di Tanah Air (Hanan, 2004).Subsidi BBM diberikan oleh pemerintah kepada Pertamina sebagai konsekuensi dari penetapan harga BBM yang dilakukan oleh pemerintah. Sebagai mana kita ketahui bahwa Pertamina melaksanakan tugas penyediaan dan pelayanan Bahan Bakar Minyak untuk keperluan dalam negeri diperintahkan oleh Undang-undang nomor 8 tahun 1971 tentang 
perusahaan pertambangan minyak dan gas bumi negara sebagai tugas pelayanan masyarakat.

Peristiwa tentang kejahatan atau tindak pidana dalam masyarakat telah mendominasi pemberitaan di Indonesia setiap harinya, baik melalui media cetak maupun media elektronik. Kejahatan tersebut antara lain mengenai penyalahgunaan BBM bersubsidi secara ilegal, merupakan kegiatan yang dengan tanpa izin mengumpulkan, menampung dan menyimpan BBM di suatu tempat yang tidak berdasarkan atau tidak sesuai dengan izin usaha pengelolaan yang mendapat rekomendasi dari pemerintah daerah yang sudah ditetapkan dalam Pasal 23 Ayat (1) Undang-Undang Republik Indonesia Nomor 22 Tahun 2001 tentang Minyak Dan Gas Bumi (Windayati, 2019). Berkaitan dengan permasalahan dalam pembatasan BBM bersubsidi, pemerintah juga mengeluarkan beberapa aturan diantaranya : (1) Permen ESDM No 12 Tahun 2012 tentang Pengendalian Penggunaan Bahan Bakar Minyak, (2) Peraturan Badan Pengatur Hilir Minyak dan Gas Bumi (BPH Migas) Nomor 3 Tahun 2012 (pengendalian jenis BBM subsidi untuk mobil yang digunakan untuk kegiatan perkebunan dan pertambangan), (3) Peraturan BPH Migas Nomor 4 Tahun 2012 (alokasi volume BBM subsidi untuk masing-masing konsumen pengguna BBM subsidi), (4) Peraturan BPH Migas Nomor 5 Tahun 2012 (Pedoman penerbitan surat rekomendasi SKPD untuk pembelian BBM subsidi).

Undang-Undang Nomor 22 Tahun 2001 tentang Minyak dan Gas Bumi ("UU Migas") mengatakan bahwa Bahan Bakar Minyak ("BBM") adalah bahan bakar yang berasal dan/atau diolah dari Minyak Bumi. Kegiatan usaha Minyak dan Gas Bumi terdiri atas Kegiatan Usaha Hulu yang mencakup: Eksplorasi dan Eksploitasi, Kegiatan Usaha Hilir yang mencakup Pengolahan, Pengangkutan, Penyimpanan, Niaga.

Ditengah kondisi sulit yang dihadapi oleh Pemerintah, akibat semakin meningkatnya permintaan BBM Bersubsidi dan naiknya harga BBM di pasar dunia, ada pihak-pihak tertentu baik perseorangan maupun korporasi yang melakukan perbuatan tidak bertanggung jawab berupa: pengoplosan, penimbunan, penyelundupan, pengangkutan dan penjualan kepada industri BBM Bersubsidi.

Perbuatan tersebut bertujuan untuk mendapatkan keuntungan bagi diri sendiri atau korporasi dengan mengorbankan kepentingan orang banyak (masyarakat). Perbuatanperbuatan dari orang-orang dan korporasi tersebut diatas, selain merugikan Negara dan dapat menimbulkan keresahan masyarakat akibat dari kelangkaan Penyalahgunaan BBM Bersubsidi, oleh karena itu perlu upaya penanggulangan yang serius dan terpadu dari semua pihak yang terkait. Adapun kriminalisasi terhadap perbuatan yang berupa penyalahgunaan BBM Bersubsidi dalam Undang-undang No. 22 Tahun 2001 tentang Minyak dan Gas Bumi. Beberapa ketentuan dalam pasalnya ternyata merupakan pidana perizinan meliputi Izin Pengolahan, Pengangkutan, Penyimpanan, dan NiagaBBM pada umumnya, dan tindak pidana meniru atau memalsukan BBM dan Gas Bumi. Hanya Pasal 55 yang khusus mengatur BBM Bersubsidi berupa menyalah gunakan pengangkutan dan/atau niaga BBM yang disubsidi Pemerintah. 
Untuk itu diperlukan pengawasan terhadap SPBU yang melakukan penjualan BBM subsidi kepada industri. Selanjutnya diatur juga dalam Permen ESDM 012013 pada Pasal 8 jelas disebutkan bahwa pelaksana kegiatan perkebunan, pertambangan, kehutanan dan transportasi laut berupa kapal barang non perintis dan non pelayaran belum dapat menyediakan, memanfaatkan, dan atau bekerja saran dengan Badan Usaha Pernegang Izin Usaha Niaga Umur nBahan Bakar Minyak atau Badan Usaha Pernegang Izin Usaha Penyimpanan maka dapat menggunakan stasiun pengisian bahan bakar rninyak non subsidi; atau stasiun pengisian bahan bakar minyak bergerak milik Badan Usaha Pemegang Izin Usaha Niaga Umum Bahan Bakar Minyak. Jadi pihak industri tidak boleh mengisi BBM di SPBU yang menyediakan BBM subsidi.

Disamping itu, ada juga badan pengatur yang melakukan pengaturan, pengawasan dan verifikasi terhadap kelancaran dan ketepatan pelaksanaan pendistribusian jenis BBM tertentu bagi konsumen pengguna supaya tepat guna. Dalam hal ini beberapa kasus penyelewengan penjualan BBM subsidi kepada industri yang dilakukan oleh SPBU di Provinsi Riau diantaranya kasus penyelewengan BBM subsidi jenis solar pada Tahun 2019 di SPBU Desa Ganting Kecamatan Salo, Kabupaten Kampar, Propinsi Riau Penjualan minyak model ini sudah jelas melanggar peraturan dan meminta pihak pertamina bersama pemerintah daerah Riau Cabut Izin SPBU Nakal Yang Memperjual belikan Subsidi keindustri, karna ini sudah sangat meresahkan masyarakat (Riau Kontras, 2020). Kasus selanjutnya juga pernah terjadi di Kabupaten Kampar juga pada Tahun 2014 dimana Polda Riau menyegel SPBU nakal di Kabupaten Kampar dimana menjual minyak solar bersubsidi ke mafia penimbunan BBM.

Dari bukti kasus tersebut terlihat telah terjadi pertentangan antara das sollen dan das seinyakni UU yang mengatur penjualan BBM bersubsidi yakni Undang-Undang Republik Indonesia Nomor 22 Tahun 2001 tentang Minyak Dan Gas Bumi Pasal 53, 54 dan 55 sertaPermen ESDM 012013 Tentang Pengendalian Penggunaan Bahan Bakar Minyak pada pasal 8 dan 9 seperti tercantum di atas, dengan fakta/kasus yang terjadi di wilayah hokum Provinsi Riau.

\section{Metode Penelitian}

Penelitian yang akan dilakukan penulis bersifat normatif, yaitu dilakukan terhadap dalam tinjauan normatif terhadap penjualan BBM Subsidi Berdasarkan Undang-Undang Republik Indonesia Nomor 22 Tahun 2001 tentang Minyak Dan Gas Bumi.Dalam penelitian hokum normative ini penulis melakukan penelitian terhadap asas-asas hukum yang bertitik tolak dari bidang-bidang tata hokum tertentu, dengan cara mengadakan identifikasi terlebih dahulu terhadap kaidah-kaidah hukum yang telah dirumuskan di dalam perundang-undangan tertentu.

Pendekatan penelitian yang digunakan untuk menjawab permasalahan penelitian adalah: (a) Pendekatan Peraturan Perundang-undangan (Statute Approach) dengan mengkaji dan menganalisis undang-undang/peraturan, (2) Pendekatan konseptual (conceptual approach) dengan penyelesaian permasalahan dalam penelitian hukum, (c) 
Pendekatan Kasus (Case Approach) dengan menelaah kasus-kasus yang berkaitan dengan isu hukum yang dihadapi.

Sumber data yang digunakan dalam penelitian hokum normatif ini adalah data sekunder yaitu Bahan Hukum Primer, Bahan Hukum Sekunder, Bahan Hukum Tertier. Sedangkan teknik pengumpulan data teknik studi documenter/studi kepustakaan yang berfungsi sebagai penunjang bukan sebagai alat untuk mendapatkan data primer. Data yang dikumpulkan selanjutnya dianalisis secara deskriptif kualitatif. Teknik analisis ini tidak mengunakan angka-angka atau statistik, namun lebih kepada penjelasan dalam bentuk kalimat yang dipaparkan secara lugas. Data yang telah dianalisis dan dideskriptifkan selanjutnya disimpulkan dengan metode deduktif, yakni menyimpulkan dari pernyataan yang bersifat umum kedalam pernyataan yang bersifat khusus

\section{Hasil Dan Pembahasan}

\section{Tinjauan Normatif Tentang Kegiatan Usaha Bahan Bakar Minyak}

Penyediaan BBM mengalami peningkatan dari tahun ketahun. Pemanfaatan Bahan Bakar Minyak (BBM), dewasa ini tidak saja berimplikasi pada kebijakan-kebijakan luar negeri suatu negara yang berpengaruh signifikan terhadap pertumbuhan ekonomi negara itu sendiri, namun juga berdampak secara global yang mengakibatkan penderitaan umat manusia. Subsidi yang dimaksud dalam hal ini adalah pemerintah menjual minyak kepada masyarakat umum dengan harga di bawah minyak dunia (BPH Migas, 2005).

Sejak berlakunya Undang-undang No. 22 Tahun 2001 tentang Minyak dan Gas Bumi, Undang-undang No. 44 Prp Tahun 1960 tentang Pertambangan Minyak dan Gas Bumi, Undang-undang No. 15 Tahun 1962 tentang Kewajiban Perusahaan Minyak Memenuhi Kebutuhan Dalam Negeri, Undang-undang No. 8 Tahun 1971 tentang Pertamina, Undang-undang No. 10 Tahun 1974 tentang Perubahan Undang-undang No. 8 Tahun 1971 tentang Pertamina tidak berlaku lagi, namun peraturan pelaksanaan dari keempat Undang-undang tersebut tetap berlaku sepanjang tidak bertentangan atau belum diganti dengan peraturan baru berdasarkan Undang-undang No. 22 Tahun 2001 tentang Minyak dan Gas Bumi. Ditengah kondisi sulit yang dihadapi oleh Pemerintah akibat semakin meningkatnya permintaan BBM Bersubsidi dan naiknya harga BBM di pasar dunia, ada pihak-pihak tertentu baik perseorangan maupun korporasi yang melakukan perbuatan tidak bertanggung jawab berupa:pengoplosan, penimbunan, penyelundupan, pengangkutan dan penjualan kepada industri BBM Bersubsidi. Perbuatan tersebut bertujuan untuk mendapatkan keuntungan bagi diri sendiri atau korporasi dengan mengorbankan kepentingan orang banyak (masyarakat).

Dari ketentuan beberapa pasal dalam Undang-undang No. 22 Tahun 2001, ternyata merupakan pidana perizinan meliputi Izin Pengolahan, Pengangkutan, Penyimpanan, dan Niaga BBM pada umumnya, dan tindak pidana meniru atau memalsukan BBM dan Gas Bumi. Hanya Pasal 55 yang khusus mengatur BBM Bersubsidi berupa menyalah gunakan pengangkutan dan/atau niaga BBM yang disubsidi Pemerintah. Perbuatan tersebut dapat dipastikan bertujuan untuk 
menguntungkan diri sendir iatau badan usaha (korporasi), tanpa memperhatikan kerugian yang ditimbulkan dari perbuatannya. Baik yang diderita oleh warga masyarakat berupa kerusakan kendaraan maupun Pemerintah (Negara) karena maksud diberikannya subsidi tidak tepat sasaran.

Oleh karena itu, maka sepatutnyalah perbuatan ini digolongkan dalam "Kejahatan" sebagaimana yang dinyatakan dalam pasal 57 ayat (2) sebagai berikut : "Tindak pidana sebagaimana dimaksud dalam Pasal 52, Pasal 53, Pasal 54, dan Pasal 55 adalah kejahatan". Mardjono (1993)mengatakan bahwa kejahatan diartikan sebagai pelanggaran atas hokum pidana, dalamUndang-undang pidana maupun ketentuanketentuan pidana dalam peraturan perundang-undangan lainnya, dirincikan perbuatan atau perilaku yang dilarang atau diancam dengan hukuman (pidana). Para pelaku kejahatan dianggap telah tidak memperdulikan kesejahteraan umum, keamanan dan hak milik orang lain (Marjono, 1993).

Subsidi adalah bantuan yang di berikan kepada produsen atau konsumen agar barang atau jasa yang di hasil kan harganya lebih rendah dengan jumlah yang dapat dibeli lebih banyak. Besar nya subsidi yang di berikan biasanya tetap untuk setiap unit barang, dengan adanya subsidi diharapkan oleh pemerintah harga barang menjadi lebih rendah. Dalam hal ini, pemerintah menanggung sebagian dari biaya produksi dan pemasaran (Susilo, 2013).Subsidi BBM sesuainaskah RAPBN dan Nota Keuangan adalah pembayaran yang dilakukan oleh Pemerintah Indonesia kepada Badan Usaha penyalur BBM, dimana pendapatan yang diperoleh Badan Usaha dari tugas menyediakan BBM di Tanah Air adalah lebih rendah dibandingkan biaya yang dikeluarkannya untuk menyediakan BBM tersebut. Apabila bernilai positif, maka selisih ini disebut Laba Bersih Minyak. Dari uraian tersebut, dapat disimpulkan bahwa pengertian atau defines subsidi adalah bantuan yang diberikan pemerintah kepada produsen atau konsumen agar barang atau jasa yang dihasilkan harganya menjadi lebih murah dan dapat dijangkau oleh masyarakat luas. Pengertian BBM bersubsidi adalah bahan bakar minyak yang di peruntukkan kepada rakyat yang telah mengalami proses subsidi. Pengertian subsidi itu sendiri adalah sebuah bantuan keuangan yang diberikan sebuah badan (dalam hal ini oleh pemerintah) kepada rakyat atau sebuah bentuk usaha. Tujuannya adalah untuk mempertahankan atau meningkatkan daya beli. Sementara untuk membantu sebuah usaha yang mengalami kemunduran, subsidi juga diperlukan agar usaha tersebut tetap menjadi tumpuan hidup banyak orang.

Subsidi BBM, sebagaimana dapat dipahami dari naskah RAPBN dan Nota Keuangan adalah "pembayaran yang dilakukan oleh Pemerintah Indonesia kepada PERTAMINA (pemegang monopoli pendistribusian BBM di Indonesia) dalam situasi dimana pendapatan yang diperoleh Pertamina dari tugas menyediakan BBM di Tanah Air adalah lebih rendah disbandingkan biaya yang di keluarkannya untuk menyediakan BBM tersebut". Dalam hal ia bernilai positif, seperti dulu sering dialami, angka itu disebut Laba Bersih Minyak. Definisi mengenai "subsidi BBM" yang dikembangkan oleh pemerintah tersebut telah diturunkan kedalam perhitungan akuntansi yang angkaangkanya kemudian menjadi dasar bagi program pemerintah untuk "menghapuskan 
subsidi BBM", termasuk perancangan program program pengurangan dampak kenaikan harga BBM. Harga BBM di Indonesia adalah harga yang diatur oleh pemerintah dan berlaku sama di seluruh wilayah Indonesia.

Permasalahan yang mulai rentan dihadapi masyarakat adalah adanya pembatasan terhadap konsumsi Minyak bersubsidi, hal ini diatur dalam Peraturan Menteri Energi Sumber Daya Mineral (Permen ESDM) Nomor 12 Tahun 2012 tentang Pengendalian Penggunaan Bahan Bakar Minyak. Ditambah dengan Badan Pengatur Hilir Minyak dan Gas Bumi (BPH Migas) Nomor 3 Tahun 2012 tentang Pengendalian jenis BBM subsidi untuk Mobil yang digunakan untuk perkebunan dan Pertambangan dan Peraturan BPH Migas Nomor 4 Tahun 2012 tentang Alokasi Volume BBM Subsidi untuk MasingMasing Konsumen Pengguna BBM Subsidi.

Kompleksnya pengaturan mengenai BBM subsidi ini menimbulkan adanya kelangkaan pasokan BBM serta sulitnya pembelian BBM di SPBU. Muncul kebingungan dari masyarakat tentang bagaimana sebenarnya pembelian BBM Bersubsidi yang sesuaia tau tidak melanggar hokum apa lagi kebutuhan minyak BBM Bersubsidi ini tidak hanya sebagai konsumsi kendaraan bermotor melainkan juga untuk kebutuhan industry baik skala kecil ataupun menengah keatas, dan itu artinya dibutuhkan adanya dokumen atau surat rekomendasi (sebagai sarana legalitas yang sah menurut hukum) untuk melakukan pembelian dan pengangkutan dengan jerigen atau drum dari SPBU.

Melalui Peraturan Pemerintah Republik Indonesia Nomor 36 Tahun 2004 tentang kegiatan usaha hilir minyak dan gas bumi Pasal 4 Huruf (i) : Yang dimaksud dengan jenis Bahan Bakar Minyak jenis tertentu dan yang termasuk dalam belanja subsidi energy antara lain Bensin, Minyak Solar dan Minyak Tanah dan/ atau Bahan Bakar Minyak jenis lain. Di Indonesia seperti yang tertera dalam APBN, Pemerintah memberikan subsidi energy untuk penggunaan BBM jenis tertentu. Namun semenjak tahun 2012 subsidi BBM jenis tertentu ini kemudian lebih dikhususkan peruntukannya. Pada BBM JenisTertentu terdiri atas Minyak Tanah (Kerosene), Bensin (Gasoline) RON 88 dan Minyak Solar (Gas Oil) atau dengan nama lain yang sejenis dengan standar dan mutu (spesifikasi) yang ditetapkan oleh Menteri Energi dan Sumber Daya Mineral.

\section{Penyelewengan BBM Subsidi}

Kriminalisasi merupakan suatu penetapan dalam Undang-undang mengenai perbuatan-perbuatan yang semula bukan suatu tindak pidana menjadi tindak pidana. Dengan ditetapkan nya suatu perbuatan sebagai tindak pidana berarti perbuatan tersebut adalah perbuatan yang dilarang dan diancam dengan pidana bagi siapa saja yang melanggar larangan tersebut. Muladi (2013), mengatakan bahwa hokum pidana dan penegakkan hokum pidana merupakan bagian dari politik (kebijakan) kriminal (criminal policy) politik criminal merupakan bagian dari politik penegakan hukum (law enforcement policy) yang mencakup pula penegakan hokum perdata dan penegakan hokum administrasi, dan politik penegakan hokum merupakan bagian politik sosial (social policy) yang merupakan usaha meningkatkan kesejahteraan warga negaranya. 
Dengan ditetapkannya perbuatan-perbuatan tertentu sebagai suatu tindak pidana (kriminalisasi) sebagai awal dari politik criminal terhadap perbuatan-perbuatan tertentu dalam masyarakat yang harus dilindungi dari perbuatan penyimpangan oleh orang atau korporasi, yang dilanjutkan dengan penegakan hukum (law enforcement) dalam rangka mencapai kemakmuran atau kesejahteraan masyarakat sebagai tujuan akhir dari politik sosial (social policy). Sistem pengawasan penyelewengan penjualan BBM Subsidi kepada industri yang dilakukan SPBU diatur berdasarkan Undang-Undang Republik Indonesia Nomor 22 Tahun 2001 tentang Minyak Dan Gas Bumi. Namun kasus penyelewengan penjualan BBM subsidi kepada industri yang dilakukan oleh SPBU di Provinsi Riau masih saja terjadi, diantaranya kasus penyelewengan BBM subsidi jenis solar pada Tahun 2019 di SPBU Desa Ganting Kecamatan Salo, Kabupaten Kampar, Propinsi Riau. Dalam kasus ini, telah dilakukan tindakan yang tertuang dalam perkara nomor 164/Pid.Sus/2020/PN Bkn dengan putusan pengadilan menyatakan Terdakwa I terbukti secara sah dan meyakinkan bersalah melakukan tindak pidana turut serta menyalahgunakan pengangkutan bahan bakar minyak yang disubsidi pemerintah dan dijatuhkanpidana masing-masing selama1 (satu) tahun 4 (empat) bulan dan denda masing-masingsebesar Rp. 100.000.000,- (seratus juta rupiah) dengan ketentuan apabila denda tersebut tidak dibayar diganti dengan pidana kurungan masing-masing selama 2 (dua) bulan. Dalam kasus ini diketahui bahwa, tersangka I dan Terdakwa II dijerat pasal 55 Jo Pasal 53 Undang-UndangRepublik Indonesia Nomor 22 Tahun 2001 tentangMinyak Dan Gas Bumi. Berdasarkan analisis penulis, kelemahan dalam peraturan yang sudah ada dalam penanggulangan penyalahgunaan BBM Bersubsidi adalah Tidak adanya ketentuan yang mengatur jumlah maksimum BBM Bersubsidi yang dapat dijual secara bebas. Serta Tidak adanya ketentuan yang jelas mengatur tentang jumlah maksimum BBM Bersubsidi yang dapat dijual secara bebas kepada masyarakat sehingga hal ini dapat disalahgunakan oleh pihak-pihak tertentu yang dengan berbagai cara atau modus dan bekerjasama dengan orang dalam membeli BBM Bersubsidi dari SPBU (Stasiun Pengisian Bahan Bakar Umum) dalam jumlah yang besar untuk dijual kembali dengan keuntungan yang besar, baik kepada masyarakat umum maupun kepada perusahaan (industri) atau bahkan di selundupkan ke luar negeri. Sehubungan dengan masalah tersebut, Muladi (2013) mengatakan: "Satu hal yang perlu diperhatikan adalah bahwa kita tidak boleh mengharapkan terlalu besar tentang peranan Sistem Peradilan Pidana sebagai pengendali kejahatan, sebab sistem ini hanya merupakan salah satu sarana saja dalam politik kriminal.

Sistem Peradilan Pidana hanya berfungsi terhadap recorded crimes yang menjadi masukannya. Fungsinya pun kadang-kadang tidak dapat bersifat maksimal (total enforcement) sebab demi menjaga keseimbangan antara ketertiban umum (public order) dan hak-hak individual (individual right) maka batas-batas penegakan hukum dibatasi oleh ketentuan-ketentuan yang ketat. Berdasarkan pendapat diatas, maka dalam penanggulangan terhadap penyalahgunaan BBM Bersubsidi, disamping dengan menggunakan sarana penal juga diperlukan pendekatan non Penal yang disebut juga sebagai pencegahan tanpa menggunakan pidana. 
Selain itu, Pada umumnya pemidanaan terhadap pelaku penyalahgunaan BBM Bersubsidi dirasakan sangat ringan dan hal ini tidak menimbulkan efek jera bagi terpidana. Dengan tidak adanya straf minimal khusus dalam ketentuan Undang- undang No. 22 Tahun 2001 tentang Migas, maka dalam pemidanaan terhadap pelaku penyalahgunaan BBM Bersubsidi Hakim berpatokan kepada straf minimal umum dalam KUHP yaitu pidana penjara 1 (satu) hari. Ini berarti Hakim dapat menjatuhkan pidana minimal 1 (satu) hari dan maksimal 6 (enam) tahun. Demikian juga halnya dengan pidana denda, tidak adanya straf minimal khusus pidana denda, dan maksimal Rp. 60.000.000.000 (enam puluh miliar rupiah). Hal ini dirasakan kurang efektif dalam penanggulangan penyalahgunaan BBM Bersubsidi, karena tidak menimbulkan efek jera bagi pelakunya. Pelaksanaan Pidana Denda terhadap Korporasi Dalam Undang-undang No. 22 Tahun 2001 tentang Migas, Badan Usaha atau korporasi dapat menjadi subjek tindak pidana penyalahgunaan BBM Bersubsidi,dan pidana yang dapat dijatuhkan adalah pidana denda paling tinggi ditambah sepertiganya. Namun tidak ada ketentuan khusus mengenai pelaksanaan pidana denda yang tidak dibayar oleh korporasi. Hal ini dapat menimbulkan masalah, karena ketentuan pelaksanaan pidana denda dalam Pasal 30 KUHP yaitu, apabila denda tidak dibayar diganti dengan pidana kurungan pengganti selama 6 (enam) bulan hanya berlaku untuk subjek "orang”, tidak untuk korporasi.

\section{Kesimpulan}

Pengelolaan gas bumi Indonesia didasarkan pada kerangka hukum yang tercantum dalamUndang-Undang Dasar tahun 1945 pasal 33 dan Undang-Undang no 22. tahun 2001 tentang Minyak dan Gas Bumi. Dalam UU No. 22 tahun 2001 termuat konsep penyelenggaraan kegiatan usaha migas, konsep penguasaan kemigasan, konsep penyediaan dan pemanfaatan kemigasan, konsep pengusahaan kemigasan dan konsep kelembagaan kemigasan. Sedangkan yang dimaksud dalam pengelolaan migas pada saat itu adalah penyediaan dan pemanfaatan yang termasuk alokasi, harga dan infrastruktur gas bumi. Alokasi dan Harga Gas Bumi teramanatkan di dalam PP no. 35 tahun 2004 tentang Kegiatan Usaha Hulu Migas sedangkan untuk infrastruktur teramanatkan dalam PP no. 36 tahun 2004 tentang Kegiatan Usaha Hilir Migas.

Penyelenggaraan kegiatan usaha Gas Bumi pada tahun - tahun tersebut bertujuan untuk meningkatkan pendapatan negara, memberikan konstribusi sebesar-besarnya bagi perekonomian nasional dan mengembangkan serta memperkuat posisi industri nasional dan perdagangan Indonesia. Sumber gas yang besar dan berada di remote area sebagian besar dimanfaatkan untuk ekspor, dikarenakan belum terdapatnya infrastruktur serta ditujukan demi kepentingan ketahan anekonominasional. Penguasaan oleh Negara atas Gas Bumi diselenggarakan oleh Pemerintah sebagai Pemegang Kuasa Pertambangan, Pengusahaannya dilaksanakan oleh Badan Usaha berdasarkan Izin Usaha, Pemanfaatan Gas Bumi bagi Konsumen dilaksanakan melalui proses penunjukan penjual Gas Bumi Bagian Negara sedangkan Pelaksanaan Kegiatan Usaha Gas Bumi dilakukan berdasarkan Rencana Induk Jaringan Transmisi dan Distribusi Gas Bumi Nasional. Sehingga dapat disimpulkan, bahwa konsep pengelolaan gas bumi pada saat 
dirumuskannya Undang-Undang Migas adalah Penyediaan dan Pemanfaatan Gas Bumi serta Pengusahaan Gas Bumi.

Sebagai implementasi Penyediaan dan Pemanfaataan Gas Bumi dilaksanakan melalui Permen ESDM No. 03 tahun 2010 tentang Alokasi dan Pemanfaatan Gas Bumi untuk Pemenuhan Kebutuhan Dalam Negeri dan kemudian ditetapkan petunjuk teknis pelaksanakannya melalui peraturan Pedoman Tata Kerja No. 029 Tahun 2009 tentang Penunjukan Penjual dan Penjualan Gas Bumi/LNG/LPG Bagian Negara.

Sedangkan untuk pengusahaannya diatur melalui Permen ESDM no. 0007 tahun 2005 tentang Persyaratan dan Pedoman Pelaksanaan Ijin Usaha Dalam Kegiatan Usaha Hilir Migas dan Permen ESDM no. 19 tahun 2009 tentang Kegiatan Usaha Gas Bumi Melalui Pipa. Permen ESDM No. 1/2013 tentang Pengendalian Penggunaan Bahan Bakar Minyak yang mengatur: - Pelarangan konsumsi BBM bersubsidi jenis premium bagi kendaraan dinas Pemerintah, BUMN \& BUMD di Jawa dan Bali, Kalimantan, Sumatera dan Sulawesi - Pelarangan konsumsi BBM bersubsidi jenis solar bagi kendaraan dinas Pemerintah, BUMN \& BUMD di Jawa dan Bali, Kendaraan Pertambangan, perkebunan dan kehutanan serta kapal barang Non Pelra dan non perintis di NKRI.

\section{Daftar Pustaka}

Afrizal, D. (2020). E-Government Service Review InDumai City Indonesia. JurnalNiara, 13(1), 260-267.

BPH Migas. (2005). KomoditasBahan Bakar Minyak (BBM), Jakarta: Penerbit BPH Migas RI.

Muladi. (2013). Kapita Selekta Sistem Peradilan Pidana, Semarang, Badan Penerbit UNDIP

Muladi. (1990) Proyeksi Hukum Pidana Material Indonesia DimasaDatang, PidatoPengukuhanJabatan Guru Besar FH UNDIP

Muladi (2013).Kapita Selekta Sistem Peradilan Pidana, Semarang, Badan Penerbit UNDIP

Nugroho, Hanan. (2004). Subsidi BBM bukan uang keluar, tapimestiditekani. Jakarta: Bisnis Indonesia.

Susilo,Sri. (2013).Bahan Bakar Minyak (BBM) \&Perekonomian Indonesia, Gosyen. Yogyakarta,Publishing

Windayati, D. (2019). TinjauanYuridisTerhadapTindakPidanaPenimbunanBahan Bakar MinyakBersubsidiJenis Solar Oleh SpbuMenurutUndang-UndangNomor 22 Tahun 2001 TentangMinyak Dan Gas Bumi (Doctoral Dissertation, Universitas Islam Sultan Agung).

Wola, M. G. (2019). Penegakan Hukum TerhadapPenjualBahan Bakar MinyakTanpaIzinMenurutUndang-UndangNomor $\quad 22 \quad$ Tahun 2001 TentangMinyak Dan Gas Bumi. Lex Et Societatis, 7(6). 